\title{
Beyond scientific contribution: Assessment of the societal impact of research and innovation to build a sustainable agri-food sector
}

\section{Nour Chams*1, Bouali Guesmi ${ }^{2,3}$ and José María Gil ${ }^{2}$}

${ }^{1}$ Polytechnic University of Catalonia (UPC), Center for Agro-food Economics and Development (CREDA). Parc Mediterrani de la Tecnologia, Edifici ESAB, 08860 Castelldefels (Barcelona), Spain.

e-mail: nour.chams@upc.edu

${ }^{2}$ Center for Agro-Food Economics and Development (CREDA-UPC-IRTA). Parc Mediterrani de la Tecnologia, Edifici ESAB, 08860 Castelldefels (Barcelona), Spain. e-mail: bouali.guesmi@upc.edu ; chema.gil@upc.edu

${ }^{3}$ University of Carthage, Mograne Higher School of Agriculture, LR03AGR02 SPADD, Zaghouan 1121, Tunisia.

\begin{abstract}
Due to the climate change and increased attention toward environmental management issues, the agri-food sector has been extensively relying on research, development, and innovation (RDi) to transform conventional agricultural production into a sustainable and eco-friendly industry. While the academic contribution of research has been relatively easily identified in the literature, the assessment of its societal impact remains underdeveloped. Accordingly, this study employs mixed-method evaluation approaches, mainly ASIRPA framework and Impact Oriented Monitoring (IOM) model to better understand and measure the multidimensional impacts of RDi in the agri-food sector in Spain. The objective of this analysis is to identify the impact of research on the society and the ecosystem. An in-depth case study analysis is conducted to examine the "best practices" program to promote sustainable techniques in the rice cultivation. Empirical findings suggest a standardized index to measure the economic, socio-territorial, health, political, capacity building, and environmental impacts, involving the stakeholder-network evaluation. The study highlights important implications for firm management decisions monitoring research uptake and policy design in the agri-food sector.
\end{abstract}

Keywords: research outcome; sustainability performance; societal impact; innovative agrifood sector. 


\section{Introduction}

The agri-food sector is considered one of the most influential industries in a country, contributing to its national welfare, poverty reduction, and food security, and participating in its economic growth—such as employment, development and technologies, income, domestic consumption, and foreign trade (Birkhaeuser et al., 1991). The aftermath of World War II saw the emergence of a new era of technological development and scientific revolution in the agricultural field (Winsberg, 1980). A drastic metamorphosis has been challenging agricultural systems to adopt innovative approaches and to integrate efficient transfer of knowledge at the macro and micro levels. Improving both the economic and environmental performances of firms is a key driver of this change (Prändl-Zika, 2008). In this regard, research, development, and innovation (RDi) play crucial roles in identifying appropriate strategies to incorporate sustainable and innovative practices into agrarian mechanisms. For instance, growing social and political concerns regarding the impact of climate change have led to extensive RDi investments to fulfill the future targets of the Sustainable Development Goals (SDGs) (UN, 2015)—i.e., well-being, minimizing hunger and malnutrition, maximizing agricultural productivity, and promoting sustainability performances (Garnett et al., 2013; Sanchez-Escobar et al., 2018; Thornton et al., 2013).

The improvement of agricultural production can be attributed to RDi investments and to the efficiency of publicly funded projects and research institutes (Cai et al., 2017). However, the evaluation process of RDi impact faces multiple challenges (e.g., time lag in productivity response, uncertainty, and risk impact) that can affect the translation of research return to the society (Alston et al., 2009). Accordingly, the methodological challenge is to quantify the multidimensional outcomes of RDi in their economic, socio-territorial, health, political, and environmental aspects. During the last decades, with the ushering of the green revolution, the research assessment has been extended to accommodate not only economic measures, but also different types of impact (Donovan, 2011; Huang and Odum, 1991). Bornmann (2013) breaks down the social impact of research scopes into three components: societal products (outputs), societal use (references), and societal benefits (changes in society). He advocates that society can benefit from science and research only if the outcomes are translated into useful products.

In the agricultural sector, remarkable studies adopt research impact assessment (RIA) 
to evaluate agri-food programs. The economic evaluation of RDi has been widely investigated in the literature (Alston et al., 2009; Anderson and Song, 2013; Bervejillo et al., 2012; Donovan, 2011). However, the assessment of their social, environmental, or sustainable impact remains extremely limited (Dendena and Corsi, 2015; Weißhuhn et al., 2017). Due to the increased attention of the European Commission (EC) and after the Lisbon Strategy (2010), the assessment framework of research is shifting to expand the scope of evaluation by integrating a wider scale of socio-economic and sustainability indicators. An important gap in RIA literature emphasizes the lack of impact-oriented assessment tools (Penfield et al., 2013); in fact, previous studies tend to be driven by research disciplines rather than being guided by the typology of impact. Therefore, further investigation must be conducted in an attempt to measure and monitor various types of impact generated from RDi and elaborate on how their scientific contribution is translated into societal contribution to the public and the ecosystem.

This study investigates how research projects on the agri-food sector are generating impact and their benefit to society by evaluating the RDi of the Institute of Agri-food Research and Technology (IRTA) in Catalonia, Spain. The aim of this analysis is to identify the societal impact of RDi and to go beyond the conventional appraisal of its economic return and academic outcome. Therefore, we conducted a case study of the five-year "best practices” program to investigate the impact of research development on rice cultivation in Spanish society. The key findings reflect a standardized tool applicable to evaluate and monitor research impact on the cultivation of various crops, as well as assisting in the accomplishment of adequate research policy planning and project management strategies.

The contribution of this research study is mainly translated to the RIA literature from both methodological and empirical points of view. Consensus is growing among policy makers and practitioners on the lack of a "single impact" to be measured and no "best approach” for doing so (Horton and Mackay, 2003; Weißhuhn et al., 2017). In contrast to previous studies, this work moves away from identifying a "unique technique"; instead, we propose a mixed-method research design to examine the multidimensional effect of agri-food RDi. To the best of our knowledge, no prior study exists in Spain that analyzes the societal impact of agricultural RDi. Furthermore, it is considered as the first study that applies the Impact Oriented Monitoring (IOM) model recently proposed by Guinea et al. (2015) to the 
agricultural research area. Finally, the implication of this study supports policymaking and regulatory formulation in the paddy and rice industries.

The remainder of the study is structured as follow. The second section comprises case study background and experimental area, providing an overview of the rice cultivation in Spain. Section three presents the methodological design, theoretical framework, and data collection. Then, in section four, key findings of the societal impact assessment are discussed. Finally, the last section highlights the major conclusions and inferences of RDi to build a sustainable agri-food sector.

\section{Case study background and experimental area}

Rice cultivation has a significant socio-cultural influence and ecological implication in the Mediterranean region of Europe (EU). The two leading rice producers in EU are Italy (51\%) and Spain (29\%), fulfilling 80\% of the European market demand. The remaining 12\% are provided by Greece and Portugal. At a global level, Spain occupies the seventeenth place as the world's largest producer and exporter of rice (FAS-USDA, 2012). Spanish rice cultivations are mainly located in three autonomous communities: Catalonia, Valencia, and Seville. In Catalonia, the total rice yield has reached 135,000 tons in 2016 and has been distributed among three provinces: Girona (6,016 tons), Lleida (223 tons), and Tarragona (129,292 tons) (Idescat, 2017). This case study focuses on one specific region of the Catalan rice production - the peninsula of the Ebro Delta, known as the primary rice producing field, located in the province of Tarragona-Catalonia and contributing to $98.5 \%$ and $20 \%$ of the total production in Catalonia and Spain, respectively. On average, the annual rice yield of the Ebro Delta reaches approximately 90,000 tons over 22,000 hectares (ha). Due to the mild climate and Protected Geographical Indication (PGI), this land is known to produce rice crops of good quality. PGI is considered as a qualification acquired based on indication, quality, and geographical origin standards (Das, 2007; Rangnekar, 2004). This classification reflects collective intellectual property rights and a signaling factor that monitor cultivation standards, protect agriculture production, and enhance rural development and profitability (Jena and Grote, 2012; Josling et al., 2004).

Rice cultivation consists of an important agricultural system that includes field management, the ecological role, and the conservation of biodiversity and the ecosystem 
(Reig-Martínez et al., 2008). The major factors affecting the agronomic characteristics of rice seeds and causing an undesirable impact on the ecosystem are identified as water type and level, fertilizers and pesticides application, and biogeography (Sabiha et al., 2016). Overall, during the last decades, rice farming has been facing critical challenges and complications in this regard. Between 1980 and 2006, the rice producing countries of the EU suffered a dramatic decrease in the number of farms (Ferrero and Tinarelli, 2008); in Italy, for instance, it was reduced to one-half, whereas in Spain it dropped to one-fifth of the total number. However, during the same period, the average surface area per farm improved due to high mechanization and technological development (Van Nguyen and Ferrero, 2006). Spain has been marked by a marginal decline ( $5 \%$ on average) in agriculture. Most of the farmers have switched from rice to corn cultivation since the latter requires less water for irrigation. Consequently, the Spanish rice-growing lands have decreased by 6\%, affecting the total rice yield (FAS-USDA, 2012). As for the Ebro Delta, the major issues threatening this peninsula are the extensive conflict between economic and developmental activities and preservation of the ecosystem and natural resources. In general, the struggle to balance optimizing economic return while minimizing environmental damages is widely seen in the agri-food sector and particularly in paddy rice cultivation. Thus, there is an emergent need to incorporate innovative and sustainable practices to facilitate the achievement of an equilibrium between economic profitability and ecological conservation.

Other critical conditions of the Ebro Delta fields have been identified: water salinity, strong northwest winds, and damage caused by the stem borer insect Chilo supressalis are unfavorable factors that negatively affect rice fields (CIHEAM, 1997). To overcome these obstacles, farmers have been shifting from traditional to sustainable cultivation, and innovative techniques have been implemented to enhance productivity through efficient assets allocation, input usage, and cost-cutting methods. However, there is still a need to educate the farmers on the importance of adopting these modern strategies. The role of research and innovation in this context is to increase awareness of quality production of rice and environmentally friendly practices among growers (i.e., land and water management, pesticides usage, and application of chemical fertilizers).

\section{Methodology}


Different methodological frameworks such as econometric modeling (Salter and Martin, 2001), surveys, and case studies (Bornmann, 2013) have been used to assess the value and outcomes of RDi. These methodologies aim to quantify the impact of scientific development on the agri-food sector translated as: agriculture productivity, farmers' skills to adopt innovative techniques, evaluation of cost reduction strategies, and improvement of resources consumption (Fuglie and Heisey, 2007). In contrast to econometric modeling, a case study approach is conducted to assess the micro-dimension of research, including impactevaluation of different stakeholders engaged in the development of the program addressed. It is considered as an appropriate tool to investigate the effect of technology and innovation (Freeman, 1984) and often used to examine the output of an individual project (Bornmann, 2013).

Due to the complexity of the innovation process and the involvement of various actors in the RDi, this analysis consists of a case study, which relies rigorously on both qualitative information as narratives and datasets, and quantitative evaluation as the stakeholders' survey. The importance of this methodological design is the triangulation of impact assessment. To mitigate self-evaluation biasness and to obtain objective assessment, this study includes the analysis of stakeholder-network participating in the program. The methodological framework comprises a mixed design of the path blazed by Joly et al. (2015) and Guinea et al. (2015). Moreover, the IOM approach has been adapted to accommodate the diversity of impact dimensions in the agriculture domain, by integrating the SocioEconomic Analysis of the Impacts of Public Agricultural Research (ASIRPA) (Joly et al., 2015). The following section elaborates on the two models applied to conduct the assessment of the societal impact of RDi.

\subsection{Theoretical framework}

The ASIRPA methodology, recently proposed by the French National Institute for Agricultural Research (INRA), overcomes the most relevant limitations associated with mainstream RIA models. It is an ex-post RIA and a comprehensive tool applied to identify the economic, societal, and environmental outcomes of research. While previous approaches consist of classic and traditional case studies based on storytelling, this framework allows accounting for the broader impact of scientific activities, without foregoing the advantages 
of the aforementioned applications. This approach mainly relies on standardized case studies, combining qualitative and quantitative techniques that have been applied across different INRA research departments (Joly et al., 2015). In this context, we intend to conduct the same analysis by adopting the aforementioned model to analyze the societal impact generated by IRTA on the Spanish agri-food sector. One attractive advantage of this methodology is its ability to take into account the contribution of the network of actors to the innovation process, as well as to scale-up the results from an individual case study to a global picture of the impact (Joly et al., 2015). Three main standardized tools underpin the ASIRPA frameworknamely, impact pathway, impact chronology, and impact vector, which represent the results of this research (Matt et al., 2017). ASIRPA has proved to be a robust, accountable, and applicable method to measure types of impact: 1) social impact; 2) environmental impact; 3) organizational impact; 4) cultural impact; and 5) political impact.

The IOM model is another innovative evaluation methodology for impact assessment. This recent RIA technique provides a straightforward and clear method to gather, organize, and discriminate between data on project results and impacts. It is mainly inspired by the Payback Model (Donovan and Hanney, 2011) and consists of two well-differentiated components: the theoretical framework component and the impact monitoring system. While the former is designed to identify and classify inputs, activities, outputs, and impacts according to time or categories (Figure 1), the latter deals with data collection and assessment tool through results framework and coordinators' survey. The advantage of this methodology is that it can be implemented during and after the project timeline to examine immediate and short-term impact, as well as to identify some potential long-term impact.

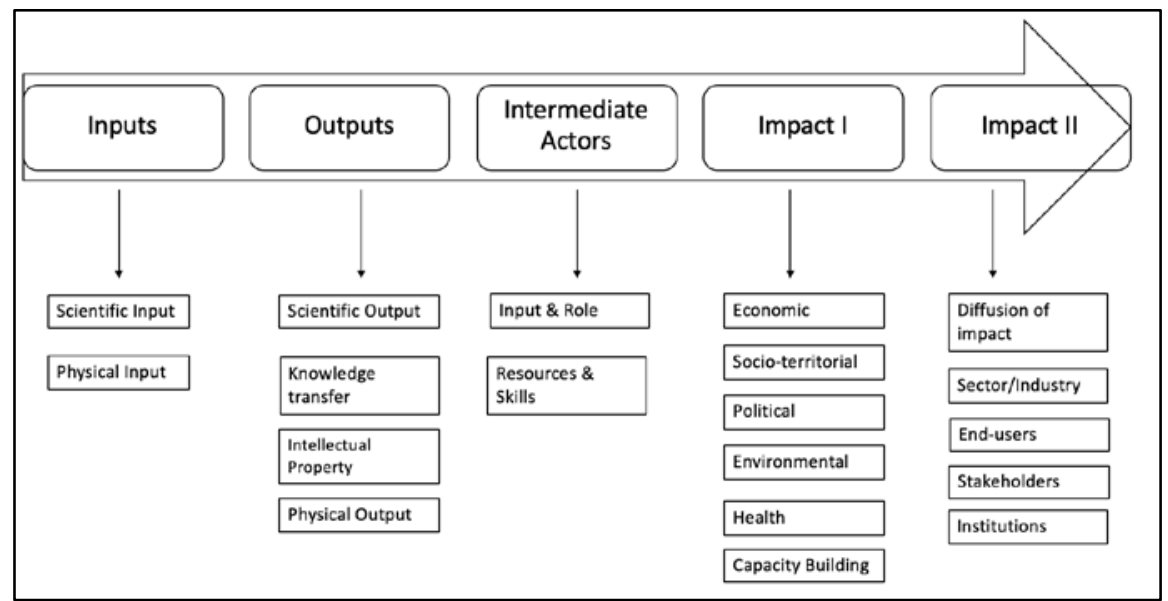

Figure 1. Impact monitoring framework 


\subsection{Methodological design and data collection}

Following previous research (Bornmann, 2013; Joly et al., 2015; Spaapen and Van Drooge, 2011), empirical application is based only on successful cases proposed by the head of the IRTA research discipline. The communication department has been contacted to collect data using "highlights: fact sheets" of research results during the last five years, from 2013 to 2018 (Gaunand et al., 2015). The innovation project (annual activity reports) of the "best practices” in rice cultivation constitutes the database of this analysis, providing detailed information on the department, title, subject type, abstract describing the innovation, topic, content, strengths, partners, products/outputs, patents, and prospects, as well as long-term impacts. As proposed by Matt et al. (2017), the selection focuses on significant research results that had or are likely to have an impact on the society. Furthermore, the innovation program is anticipated to reveal not only academic contribution, but also non-academic impact. According to the recent scientific standards (Research Evaluation Framework REF, 2011), the selected case is expected to reveal diversified outcomes positively influencing farmers and regulatory agents in the rice industry.

Apart from the categories described in the IOM methodology (i.e., knowledge production; research targeting and capacity building; informing policy and product development; dissemination and knowledge transfer), additional components are included to reflect the characteristics of the agri-food sector. Similar to ASIRPA, six dimensions have been defined to measure the impact of agricultural science on society: economic, environmental, political, socio-territorial, health, and capacity building. The quantification and qualification of impact mainly rely on descriptors gathered from an exhaustive literature review (De Jong et al., 2014). Accordingly, the first step of this study consists of a content analysis of case studies of RDi from INRA and IRTA. The aim is to identify a list of standardized parameters applicable to different agri-food domains and build a homogenous index to measure the multidimensional impact.

Three analytical tools have been integrated, consisting of: 1) project results framework; 2) coordinators' survey; and 3) assessment tool (scoring matrix). Structured interviews and open-ended questions were firstly addressed to several actors contributing to the development of the program (researchers, project managers, directors, stakeholders, policy makers and experts, etc.). Comprehensive data were collected in order to achieve an 
overview of the research evaluation (Figure 2), and information obtained from the interviews was gathered and summarized through systematic measurable indicators.

The stakeholder survey was distributed to all the actors participating in the research program. The total number of respondents is distributed as follows: project coordinator (1/1); co-partner (1/1); intermediary actors (8/8); technical support (5/5); and end-users (farmers) (13/45). The program coordinator and co-partner tend to be highly evaluated compared to the other types of stakeholders due to their skills, expertise, and level of engagement in the program development (Bacharach and Lawler, 1980). According to Brandon et al. (1998), the "program personnel” (i.e., project coordinator and co-partner) have considerably more knowledge compared to others - thus, they exert more influence on the evaluation decisions (Cousins and Whitmore, 1997). Based on a ten-point rating scale, participants were asked to grade the importance of each sub-indicator and to weigh the importance of each impact reflecting the perspective of each actor. The assigned score represents the average of its subdimension scores. Average scores are obtained using sampling weights to correct over/under sampling of observations and provide unbiased estimates. Figure 2 summarizes the steps followed in the methodological model applied to conduct the case study analysis.

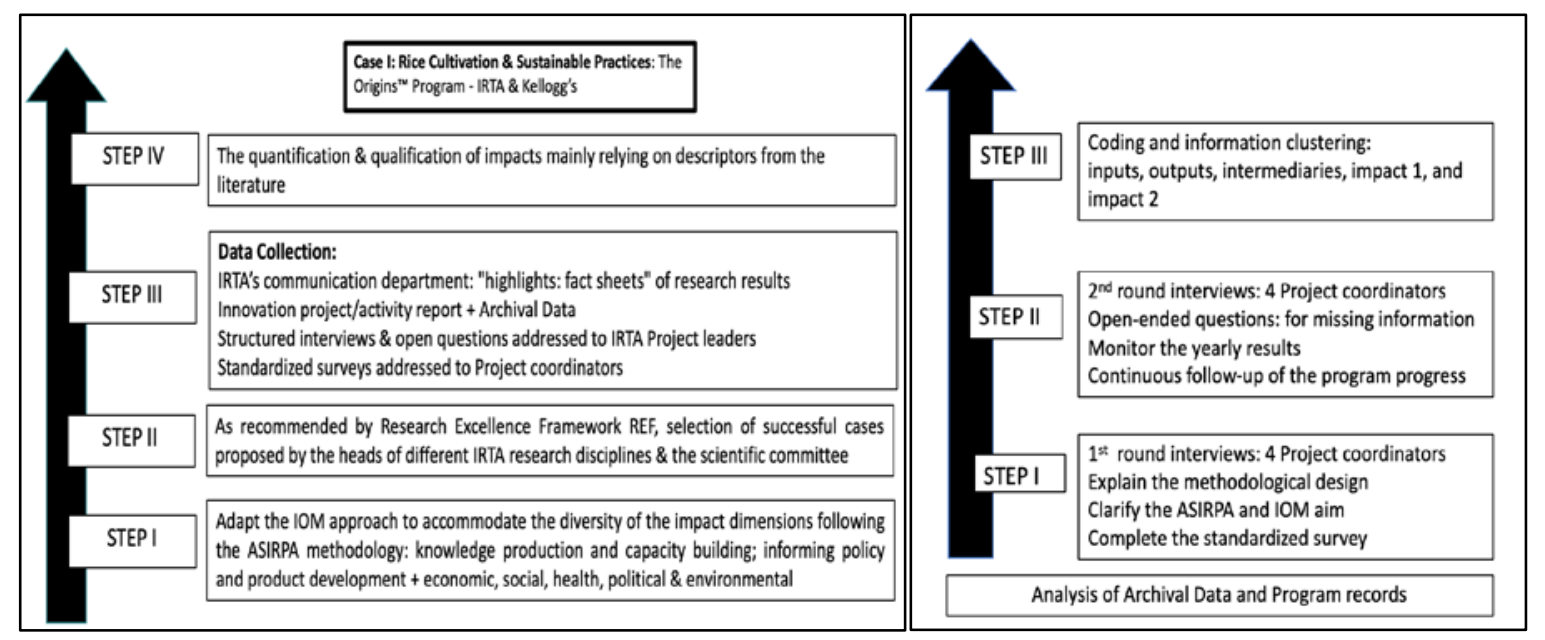

Figure 2. Methodological design of the study

\section{Results and discussion: “The best practices" case study}

In 2013, the "Origins ${ }^{\mathrm{TM}}$ Project - The best practices" was launched with the aim of transforming the Ebro Delta fields into a sustainable peninsula of rice cultivation. The objective of this research development is to provide a voluntary opportunity for rice farmers 
to improve cost effectiveness, optimize resources usage, increase productivity and yield, and maximize economic return (The Kellogg's Origins ${ }^{\mathrm{TM}}$ Program, 2019). This initiative combines farming mechanisms and food production with mutual concern toward integrating efficient and sustainable supply chain systems in the crops industry (Stobart et al., 2015). Moreover, the motivation behind this collaboration is to offer consumers a healthy, balanced cereal product, manufactured from sustainable cultivated rice grains and responsible plantation, taking into account environmental conservation. The purpose of the program is to promote efficient management and allocation of resources and to minimize the harmful impact of agriculture on the ecosystem by adopting environmental-friendly strategies.

The major driver for developing this RDi program is the improvement of the sector's competitiveness, ensuring a sustainable and quality production in the Spanish market. The "best practices" program consists of exploring and developing various scientific and practical techniques in rice cultivation, such as plant material evaluation trials (i.e., grain yield, seed quality, and evaluation of plant disease); fertilization trials (i.e., design trials and monitoring treatments); and transfer services (i.e., survey application to farm sector, results transfer, and technology adoption) (Stobart et al., 2015).

The results of this analysis are classified into different categories monitoring the impact during and after the project timeline. Empirical findings reveal the inputs, outputs, knowledge flow and dissemination, and impact of the research program. Figure 3 represents the impact chronology, identifying major events related to the rice industry and reflecting both the European and project contexts. 


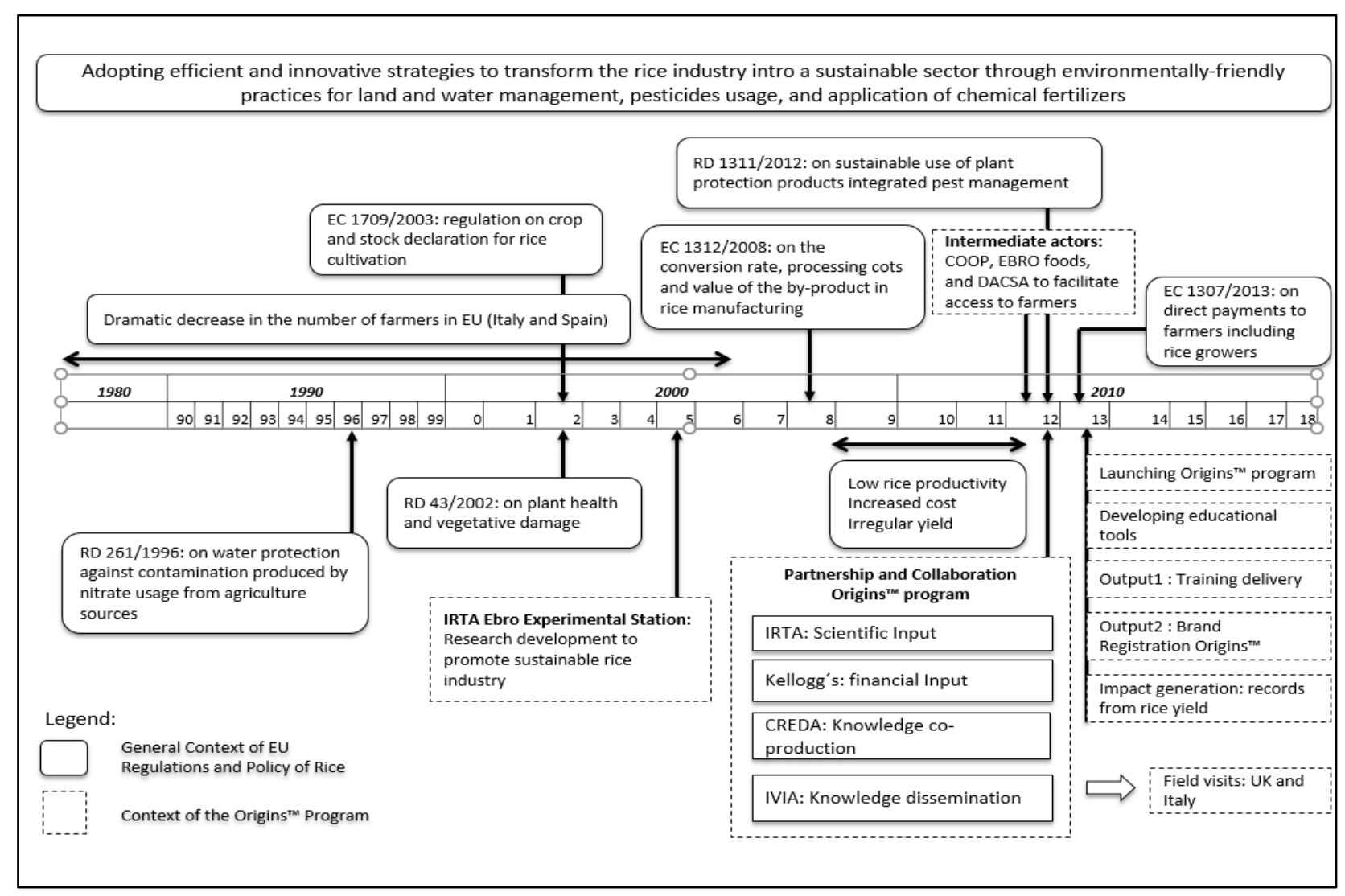

Figure 3. Impact chronology

\subsection{Input}

Both researchers and practitioners have been emphasizing the transition that the agri-food sector is undergoing in order to achieve sustainable performances (Loorbach et al., 2017; Markard et al., 2012; OECD, 2011). RDi play a crucial role in implementing eco-friendly strategies and promote farmers' awareness toward balancing profitability and the ecosystem (Bilali, 2019). In this context, the research project contributes to transforming the rice sector from a conventional to a sustainable cultivation system. The research institute provides scientific inputs to initiate the adoption of sustainable practices in rice plantations. These techniques consist of improving crops quality, irrigation systems, efficient use of water, fertilization, and field preparation (Lu et al., 2010; Noya et al., 2018). Such inputs are classified as assemble and transfer of knowledge (Argote and Ingram, 2000; Hamdoun et al., 2018), technical development, and scientific leadership (Guinea et al., 2015); they consist of building a strong connection with the primary rice sector by fostering communication capacity and human capital. 
Kellogg's Company, in its role of co-partner, is the financial capstone of this RDi. Some of its cereal products rely considerably on the rice produced from the Ebro Delta Natural Park (Ebro foods, 2018). In this context, the aim of this collaboration is to incorporate the "best practices” program in Spain along with implementing innovative and sustainable performances in the rice sector. The project's purpose is to promote mechanisms based on three pillars: social, economic, and ecological.

This research collaboration targets and solves a problem of public interest in the agrifood industry and generates a set of new normative implications for rice farmers. Each actor provided a set of resources and assets to attain the objectives of the program and accomplish the desired outcomes. The three stages of project implementation consisted of: initiation of know-how by delivering training sessions and conducting workshops; practical implication on field by growing a plot adopting sustainable practices; evaluation, communication, and dissemination by sharing the knowledge acquired within and across farmers’ groups.

\subsection{Output}

The preliminary output of the project-delivering the first training session to farmers-was dated May 2013. The scientific output consisted of a program workshop and development of educational material to enhance sustainable practices in agriculture. The training content comprised in-class lectures and practical coursework in labs or field (applied topics, technical sheets, videos, and round table discussion); field days as showcases (critical time, feedback, and farmers' support for adaptation); trips and visits to various rice fields (Andalucía, Aragon, and Navarra). Over five years, from 2013 to 2018, the annual output expanded and targeted a higher number of farmers and a larger surface of rice cultivation. For instance, in 2013, the workshop was delivered to 16 farmers consisting of eight ha and four showcases; in 2014, the number of farmers increased to 35 in total, 15 showcases and 74 ha, while in 2015 the surface area of rice growing had increased by more than 33 times since the starting date of the program, reaching 1200 ha, 54 farmers and 15 showcases. The latest results indicate an increase in the number of farmers (71) voluntarily implementing such "best practices” in agriculture.

Elaborating on this RDi, the outcome is classified as "capacity building” and “knowledge transfer” through learning tools of academic and scientific advancement (Figure 
4). Two main outputs are identified: the scientific output (i.e., published articles in press, emagazines, reports, educational manuals, and training material) that has been presented in national and international conferences; and intellectual property rights as brand registration of the Origins ${ }^{\mathrm{TM}}$ project. Adoption of the "best practices", post-evaluation, and follow-ups through "customized assistance" are the strategies incorporated to spread knowledge production in different regions and to several producers. The adopted practices (i.e., land preparation, water management, fertilization, weeds management, pest management, and disease management) reveal better social, economic, and environmental performances (Altieri and Nicholls, 2004; Gurr et al., 2004; Holland, 2004).

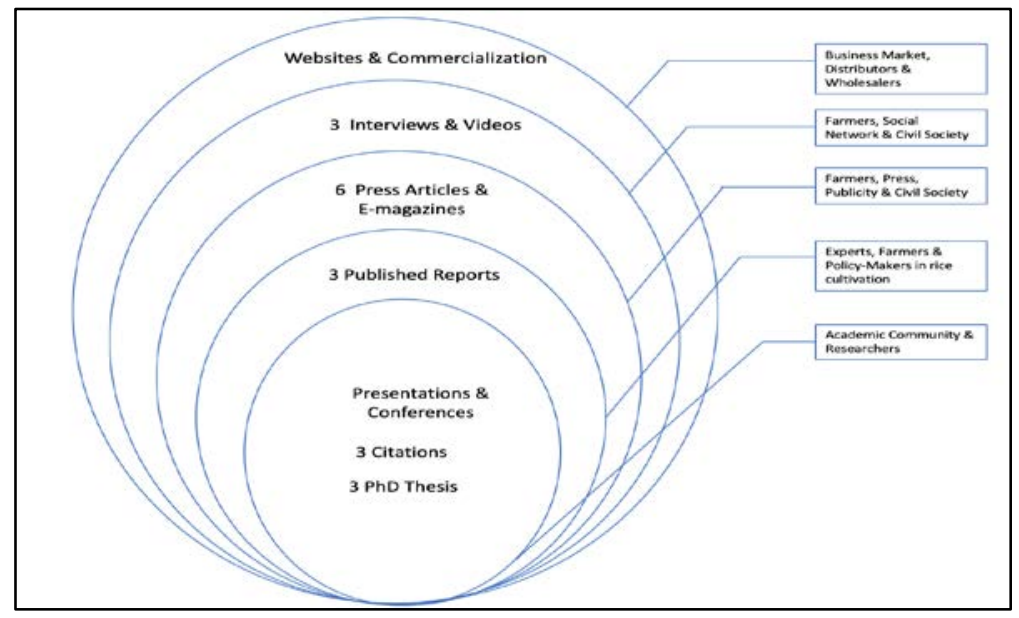

Figure 4. IRTA's scientific output

\subsection{Knowledge flow and dissemination}

The key factors guaranteeing an efficient and consistent knowledge flow and dissemination of the outputs are communication channels and coordination among the stakeholder-network such as farmers, institutions, firms, researchers, and technicians (Cvitanovic et al., 2016; Lwoga et al., 2011). The two phases for transmitting the know-how and scientific development consist of theoretical formation and practical application. Following the intensive workshops, farmers apply the knowledge acquired through showcase plots, cultivating new rice fields and monitoring them throughout the season. An important challenge is to make the training accessible to a higher number of farmers and the content easy to acquire and beneficial to all participants. Other tools of diffusion and evaluation are the development of communication means and marketing strategies. The main intermediary 
actors facilitating the process of knowledge transfer and dissemination are the Center for Agro-food Economics and Development (CREDA) for knowledge co-production and costbenefit analysis; the Valencian Institute of Agricultural Research (IVIA) to integrate sustainable techniques into Valencian lands; Cooperative organizations (Càmara Arrossera del Montsià and Arrosssaires Delta de l'Ebre) and leading companies in the Catalan rice industry (Ebro Foods and DACSA) for key access to rice producers and farmers.

At the regional level, the outcome of the RDi is perceived as a "model," transferring knowledge to other rice fields. The corresponding sustainable practices have been implemented in a considerably modest way in Valencia and Seville, tackling water conservation and greenhouse gas (GHG) emission reduction. At the global level, the "best practices” program has been effective since 2013 in various European regions (such as the United Kingdom (UK), Italy, Spain, etc.) (Stobart et al., 2015) through the Global Supplier Code of Conduct. Experts and researchers in the field train and provide access to theoretical and practical support of agricultural systems and implement social and eco-friendly performances.

\subsection{Impact assessment}

Research impact is perceived as both technical and practical improvement, by promoting awareness and the well-being of rice farmers. It is described as the amelioration of rice quality, economic return, and enhancement of environmental protection. Since 2013, the average yield produced has been increasing incrementally compared to the average yield of the Ebro Delta, with an average annual growth of $15 \%$. As reported by the project coordinator, in 2018 more than 27\% of Ebro Delta lands applied sustainable practices. The cultivation methods included soil analysis, planting techniques, fertilization dosage and frequency, water and land management, and the identification and monitoring of weeds, pests, and diseases. The rice produced in the Ebro Delta is considered the main raw material in Kellogg's breakfast products, which are exported to more than 20 countries all over the world (Ebro, 2018).

The broader impact of this case study is classified as follows: high-medium level for capacity building, environmental, and health impact; medium-low level for economic, socioterritorial, and political impact (Figures 5 and 6). Figure 5 displays the impact pathway of 
RDi, summarizing the major inputs, outputs, and intermediaries, and scaling up and scaling down the multidimensional impact (1 and 2).

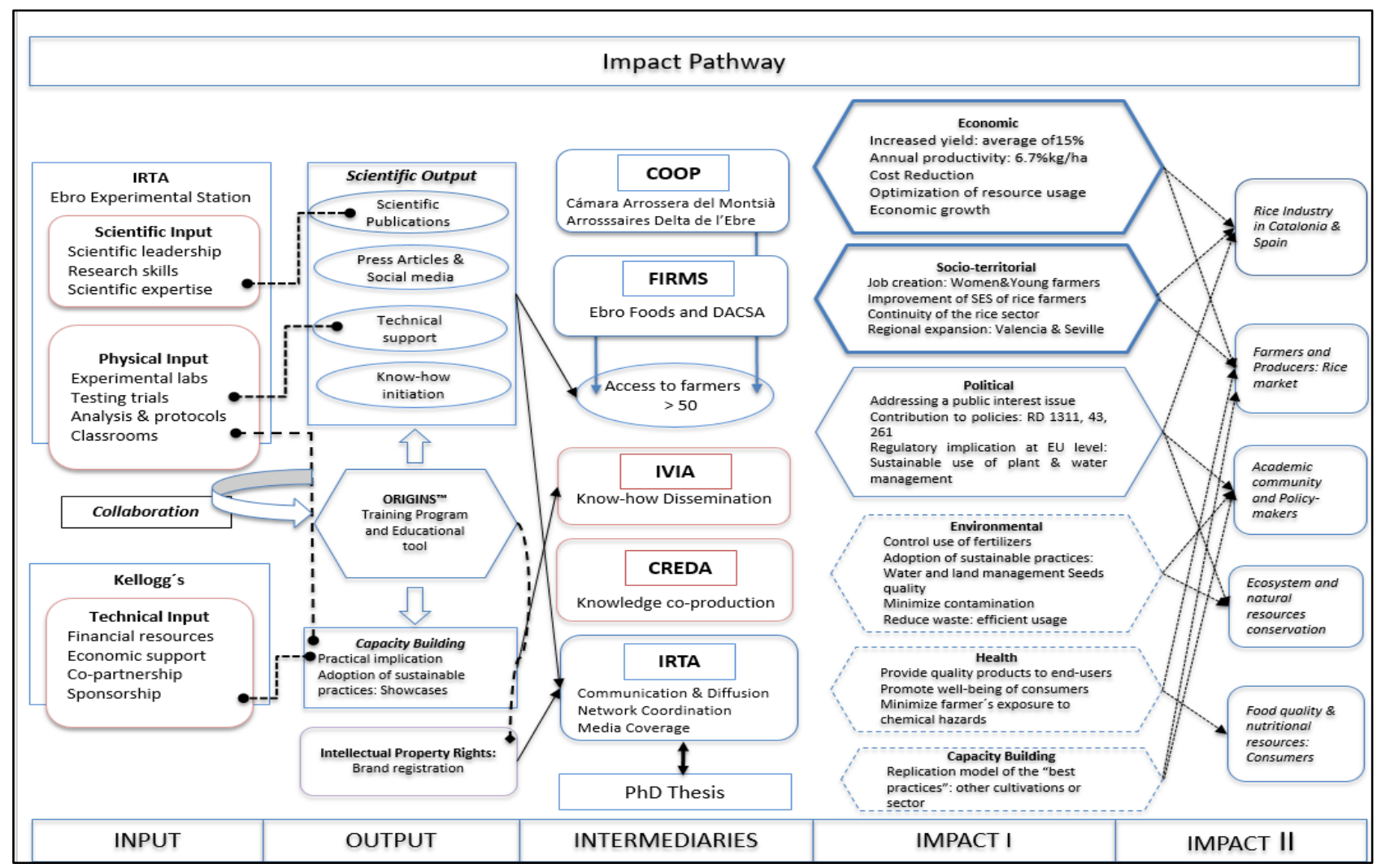

Figure 5. Impact pathway

\subsubsection{Economic impact}

The economic impact of this research project (Table 3) is measured by a set of indicators as the effect on productivity, expenses, and economic contribution to the growth of the Spanish rice industry (Acosta and Curt, 2019; Sanchez-Escobar et al., 2018; Witzke and Noleppa, 2016). Results show an economic improvement between 2013 and 2018. Applying the new techniques for land management and effective allocation of resources (sun exposure, saline or non-saline water, fertilizers and pesticides, phytosanitary and soil quality, etc.) has led to an increase in rice yield, profitability, and minimization of costs. The training program helped farmers optimize their production through the implication of sustainable performances. Between 2013 and 2018, the total rice production (kg/ha) increased with an average growth of $15 \%$. Table 1 displays the annual production change of rice, providing a comparison of 
yields between Vitrines Delta (fields implementing sustainable practices) and the remaining cultivated lands of the Ebro Delta.

\begin{tabular}{|l|r|r|r|r|r|}
\hline \multicolumn{7}{|c|}{ Production (Kg/ha) } \\
\hline Year & Number of Farmers & Hectares Cultivated & Ebro Delta & Vitrines Delta & \% Change \\
\hline $\mathbf{2 0 1 3}$ & 16 & 1637 & 6.840 & 7.661 & $\mathbf{1 2 . 0 0}$ \\
\hline $\mathbf{2 0 1 4}$ & 32 & 3142 & 6.532 & 7.319 & $\mathbf{1 2 . 0 5}$ \\
\hline $\mathbf{2 0 1 5}$ & 41 & 3661 & 6.566 & 7.832 & $\mathbf{1 9 . 2 8}$ \\
\hline $\mathbf{2 0 1 6}$ & 41 & 3661 & 7.020 & 7.387 & $\mathbf{5 . 2 3}$ \\
\hline $\mathbf{2 0 1 7}$ & 58 & 4454 & 6.600 & 7.030 & $\mathbf{6 . 5 2}$ \\
\hline $\mathbf{2 0 1 8}$ & 13 & 2870 & 6.840 & 9.114 & $\mathbf{3 3 . 2 5}$ \\
\hline
\end{tabular}

Table 1. Rice productivity of Ebro Delta between 2013 and 2018

Productivity improvement has an explicit impact on the socio-economic status of farmers and cultivators, allowing the rice industry to blossom and promoting better life conditions. Table 2 provides a cost-benefit analysis of three showcases. Showcases on fertilizer's dosage (ammonium sulfate) and optimization of resources reveal a considerable positive effect on the net farm income.

\begin{tabular}{|c|c|c|c|c|c|c|}
\hline \multirow{3}{*}{ Best Practices } & \multicolumn{6}{|c|}{ Showcase Water Impact: Irrigation with salty water and poor soil } \\
\hline & \multicolumn{3}{|c|}{2013} & \multicolumn{3}{|c|}{2014} \\
\hline & Revenue & Expenses & Profit & Revenue & Expense & Profit \\
\hline Average & 732.33 & 657.40 & 74.93 & 721.15 & 667.83 & 53.33 \\
\hline \% Change Exp. & \multicolumn{6}{|c|}{1.59} \\
\hline \% Change Profit & \multicolumn{6}{|c|}{-28.83} \\
\hline \multirow{3}{*}{ Best Practices } & \multicolumn{6}{|c|}{ Showcase Fertilizers' Impact: Ammonium Sulfate } \\
\hline & \multicolumn{3}{|c|}{2015} & \multicolumn{3}{|c|}{2016} \\
\hline & Revenue & Expenses & Profit & Revenue & Expenses & Profit \\
\hline Average & 771.30 & 664.60 & 106.70 & 831.03 & 642.57 & 188.40 \\
\hline \% Change Exp. & & & & & & \\
\hline \% Change Profit & & & & & & \\
\hline \multirow{3}{*}{ Best Practices } & \multicolumn{6}{|c|}{ Showcase Optimization of resources Impact: Efficient Usage } \\
\hline & \multicolumn{3}{|c|}{2016} & \multicolumn{3}{|c|}{2017} \\
\hline & Revenue & Expense & Profit & Revenues & Expenses & Profit \\
\hline Average & 831.03 & 642.56 & 188.4 & 881.56 & 672.4 & 209.17 \\
\hline \% Change Exp. & \multicolumn{6}{|c|}{4.64} \\
\hline
\end{tabular}


$\%$ Change Profit

11.02

Table 2. Economic impact: cost-benefit analysis (euro $€ /$ per hectare)

\begin{tabular}{|l|r|r|r|r|r|r|}
\hline ECONOMIC IMPACT EVALUATION & $\begin{array}{c}\text { Sub- } \\
\text { indicators }\end{array}$ & Coordinator & \multicolumn{1}{c|}{$\begin{array}{c}\text { Co- } \\
\text { partner }\end{array}$} & Intermediary & $\begin{array}{c}\text { Technical } \\
\text { support }\end{array}$ & $\begin{array}{c}\text { End- } \\
\text { users }\end{array}$ \\
\hline Increase yield and productivity & 8.07 & 7.00 & 8.00 & 7.64 & 9.48 & 8.00 \\
\hline $\begin{array}{l}\text { Minimize losses: reduce costs through } \\
\text { optimization of resources usage }\end{array}$ & 7.14 & 8.00 & 8.00 & 7.10 & 9.3 & 6.87 \\
\hline Maintain economic growth of the sector & 7.01 & 6.00 & 7.00 & 6.87 & 9.02 & 6.82 \\
\hline Development of SMEs and Spin-offs & 4.70 & 7.00 & 5.00 & 4.67 & 5.22 & 4.58 \\
\hline $\begin{array}{l}\text { Improve the Catalan-Spanish market } \\
\text { competitiveness : export and import balance }\end{array}$ & 5.38 & 5.00 & 6.00 & 4.07 & 6.62 & 5.45 \\
\hline $\begin{array}{l}\text { Build a sustainable value chain of the sector } \\
\text { by new market entry }\end{array}$ & 5.48 & 6.00 & 5.00 & 3.70 & 7.22 & 5.57 \\
\hline Introduce innovative techniques & 7.18 & 8.00 & 9.00 & 7.27 & 7.96 & 7.03 \\
\hline Job creation and employment opportunities & 5.35 & 5.10 & 8.00 & 4.53 & 5.34 & 5.43 \\
\hline Average of economic impact & $\mathbf{6 . 4 1}$ & $\mathbf{6 . 5 1}$ & $\mathbf{7 . 0 0}$ & $\mathbf{5 . 7 3}$ & $\mathbf{7 . 5 2}$ & $\mathbf{6 . 2 2}$ \\
\hline Importance weight of economic impact (\%) & $\mathbf{2 3 . 4 6}$ & $\mathbf{2 0 . 0 0}$ & $\mathbf{2 5 . 0 0}$ & $\mathbf{2 0 . 0 0}$ & $\mathbf{1 9 . 0 0}$ & $\mathbf{2 4 . 6 2}$ \\
\hline Sample size (N) & $\mathbf{2 8}$ & $\mathbf{1}$ & $\mathbf{1}$ & $\mathbf{8}$ & $\mathbf{5}$ & $\mathbf{1 3}$ \\
\hline
\end{tabular}

Table 3. Stakeholders' evaluation of the economic impact

\subsubsection{Political impact}

The evaluation of political impact (Table 4) relies on various indicators such as the contribution to public debate and policy negotiation, the use of policymaking, and the societal importance of the policy domain at stake. Following Gaunand et al.’s (2017) measure, the global “political impact” level represents a weighted average score of three dimensions. A factor of one was assigned to the first two dimensions, while a weighting factor of three was attributed to the importance of the policy domain at stake. In this context, political impact is translated as the important role of RDi in addressing an issue of public interest within the crops industry and by providing new insights and scientific support to rice farmers. As a result, the program has an implication at the regulatory level, supporting the application of Spanish and EU policies; it has a direct impact on 1) the sustainable use of plant protection products and integrated pest management (Royal Decree RD 1311/2012), 2) plant health and vegetative damage (Royal Decree RD 43/2002), and 3) the protection of water against the contamination produced by nitrates from agricultural sources (Royal Decree RD 261/1996); an indirect impact on processing costs and value of byproducts for the various stages of rice processing (European Commission EC 1312/2008).

\begin{tabular}{|l|c|c|c|c|c|c|}
\hline POLITICAL IMPACT EVALUATION & $\begin{array}{c}\text { Sub- } \\
\text { indicators }\end{array}$ & Coordinator & $\begin{array}{c}\text { Co- } \\
\text { partner }\end{array}$ & Intermediary & $\begin{array}{c}\text { Technical } \\
\text { support }\end{array}$ & $\begin{array}{c}\text { End- } \\
\text { users }\end{array}$ \\
\hline Use in public debate \& policy negotiation & & & & & \\
\hline
\end{tabular}




\begin{tabular}{|l|r|r|r|r|r|r|}
\hline $\begin{array}{l}\text { Quality and strength of research messages } \\
\text { conveyed }\end{array}$ & 6.61 & 9.80 & 1.00 & 5.87 & 8.86 & 6.50 \\
\hline Intensity and quality of media coverage & 5.89 & 9.40 & 7.00 & 6.07 & 6.24 & 5.72 \\
\hline Intensity and quality of debate & 5.44 & 4.90 & 1.00 & 3.65 & 4.94 & 5.88 \\
\hline Use for policy making & & & & & & \\
\hline $\begin{array}{l}\text { Stages of the policy cycle affected: agenda- } \\
\text { setting, formulation, implementation and } \\
\text { evaluation of policies }\end{array}$ & 4.72 & 0.10 & 1.00 & 3.50 & 3.48 & 5.24 \\
\hline Territorial scales of policies affected & 4.60 & 0.10 & 1.00 & 3.72 & 3.28 & 5.09 \\
\hline $\begin{array}{l}\text { Relevance and novelty of the solution } \\
\text { provided for the policy }\end{array}$ & 4.58 & 0.10 & 1.00 & 3.92 & 4.04 & 4.94 \\
\hline Societal importance of the policy domain at stakes & & & & & & \\
\hline $\begin{array}{l}\text { Magnitude of the affected population and } \\
\text { policy }\end{array}$ & 5.36 & 0.90 & 8.00 & 3.87 & 4.70 & 5.70 \\
\hline Societal concerns & 5.08 & 7.60 & 8.00 & 5.28 & 6.00 & 4.82 \\
\hline Total average of political impact & $\mathbf{5 . 2 6}$ & $\mathbf{4 . 1 1}$ & $\mathbf{3 . 5 0}$ & $\mathbf{4 . 4 8}$ & $\mathbf{5 . 1 9}$ & $\mathbf{5 . 4 9}$ \\
\hline Importance weight of political impact (\%) & $\mathbf{2 . 1 1}$ & $\mathbf{5 . 0 0}$ & $\mathbf{0 . 0 0}$ & $\mathbf{1 . 6 0}$ & $\mathbf{2 . 3 1}$ & $\mathbf{1 . 2 5}$ \\
\hline Sample size (N) & $\mathbf{2 8}$ & $\mathbf{1}$ & $\mathbf{1}$ & $\mathbf{8}$ & $\mathbf{5}$ & $\mathbf{1 3}$ \\
\hline
\end{tabular}

Table 4. Stakeholders' evaluation of the political impact

\subsubsection{Socio-territorial impact}

This research program reveals socio-territorial implications in rural areas, influencing farmers' socio-economic status and providing new job opportunities for women and young farmers (Table 5). The age range of rice growers participating in the program varies between 18 and 70 years old, with an average of 44. Accordingly, the socio-territorial impact is translated through employment creation, women empowerment in the agri-food sector, and by enhancing the appeal of the rice industry to the young generation. Currently, among the participants, ten farmers are women. This can be interpreted as an indication of how RDi contribute to the socio-financial conditions and territorial management of the rice industry. Through modernization and land usage, the outcome of this research enhances the prosperity of the sector supporting autonomous growers to maintain decent living standards and the continuity of their family businesses. Furthermore, the rice fields of the Ebro Delta have been classified as cultivated lands with the Protected Geographical Indication (PGI) (EC 1107/96).

\begin{tabular}{|l|r|r|r|r|r|r|}
\hline $\begin{array}{l}\text { SOCIO-TERRITORIAL IMPACT } \\
\text { EVALUATION }\end{array}$ & $\begin{array}{c}\text { Sub- } \\
\text { indicators }\end{array}$ & Coordinator & $\begin{array}{c}\text { Co- } \\
\text { partner }\end{array}$ & Intermediary & $\begin{array}{c}\text { Technical } \\
\text { support }\end{array}$ & End-users \\
\hline $\begin{array}{l}\text { Improvement of farmers' conditions: } \\
\text { improve socio-economic status and } \\
\text { decent life standards }\end{array}$ & 7.62 & 6.10 & 9.00 & 5.80 & 6.70 & 8.01 \\
\hline $\begin{array}{l}\text { Job creation for women and young } \\
\text { farmers }\end{array}$ & 6.86 & 6.10 & 9.00 & 4.74 & 6.96 & 7.15 \\
\hline $\begin{array}{l}\text { Continuity of family business in the agri- } \\
\text { food sector }\end{array}$ & 6.81 & 7.00 & 9.00 & 6.30 & 8.54 & 6.65 \\
\hline Geographical Indication labelling & 6.13 & 5.00 & 5.00 & 4.43 & 5.68 & 6.51 \\
\hline
\end{tabular}




\begin{tabular}{|l|r|r|r|r|r|r|}
\hline $\begin{array}{l}\text { Sustain the Spanish cultivation- } \\
\text { production: market expansion local and } \\
\text { global }\end{array}$ & 6.42 & 5.00 & 7.00 & 6.11 & 6.78 & 6.45 \\
\hline $\begin{array}{l}\text { Patents exploitation: national and } \\
\text { international diffusion }\end{array}$ & 5.18 & 5.00 & 3.00 & 2.90 & 3.48 & 5.78 \\
\hline $\begin{array}{l}\text { Territorial management and landscape } \\
\text { efficiency }\end{array}$ & 6.27 & 7.00 & 9.00 & 6.70 & 5.56 & 6.20 \\
\hline Land-use planning operations & 5.75 & 5.00 & 9.00 & 6.60 & 5.22 & 5.62 \\
\hline $\begin{array}{l}\text { Platform for maintenance of the resource } \\
\text { and the landscape }\end{array}$ & 5.07 & 5.00 & 9.00 & 6.37 & 7.06 & 5.39 \\
\hline Promote sustainable rural development & 6.85 & 8.00 & 10.00 & 7.70 & 9.18 & 6.36 \\
\hline $\begin{array}{l}\text { Total average of socio-territorial } \\
\text { impact }\end{array}$ & $\mathbf{6 . 3 8}$ & $\mathbf{5 . 9 2}$ & $\mathbf{7 . 9 0}$ & $\mathbf{5 . 7 7}$ & $\mathbf{6 . 5 2}$ & $\mathbf{6 . 4 1}$ \\
\hline $\begin{array}{l}\text { Importance weight of socio-territorial } \\
\text { impact (\%) }\end{array}$ & $\mathbf{1 5 . 0 0}$ & $\mathbf{1 0 . 0 0}$ & $\mathbf{1 5 . 0 0}$ & $\mathbf{1 4 . 3 8}$ & $\mathbf{1 7 . 0 0}$ & $\mathbf{1 5 . 0 0}$ \\
\hline Sample size (N) & $\mathbf{2 8}$ & $\mathbf{1}$ & $\mathbf{1}$ & $\mathbf{8}$ & $\mathbf{5}$ & $\mathbf{1 3}$ \\
\hline
\end{tabular}

Table 5. Stakeholders' evaluation of the socio-territorial impact

\subsubsection{Environmental impact}

Previous studies indicate that agriculture produces drastic damages to the ecosystem, such as the emission of GHG, water contamination, and food security (Hussain et al., 2014; Liao et al., 2018; Miller et al., 2019). Some strategies can mitigate the harmful environmental impact of rice plantations. Through this RDi, two techniques were adopted by Ebro farmers to promote efficient, sustainable cultivation. An important contribution of this case study relies on the fact that the program helps farmers be efficient through a more rational and less arbitrary use of fertilizers and pesticides. The latter has a positive implication toward natural resources and environmental conservation (Table 7). One of the main interventions implies controlling for time, frequency, and dosage of fertilizers (nitrogen $\mathrm{N}$, potassium $\mathrm{K}$, and phosphorous P) (Zhao et al., 2010). Adequate fertilization reduces losses and contamination, while optimizing the consumption of resources (Sabiha and Rahman, 2018). Farmers were encouraged to avoid the excessive use of nitrogen, introducing sufficient amounts of potassium and minimizing the use of seeds. Table 6 displays the outcomes of one showcase on resource optimization strategies.

\begin{tabular}{|c|c|c|c|c|}
\hline \multicolumn{4}{|c|}{ Optimization of Resources' Usage } & \\
\hline Farmers & $\begin{array}{c}\text { Productivity } \\
\text { (Kg/ha) }\end{array}$ & $\begin{array}{c}\text { Net Profit } \\
(€ / h a)\end{array}$ & Expenses & \\
\hline \multirow{3}{*}{ Farmer A } & \multirow{3}{*}{8.721} & \multirow{3}{*}{907} & Adob: 174-50-36: $260 € /$ ha & \multirow{3}{*}{$\begin{array}{c}\text { Higher } \\
\text { Profit Les } \\
\text { Pesticides }\end{array}$} \\
\hline & & & 2 Herbicides: Ronstar/BasagranM: $86 €$ €/ha & \\
\hline & & & 2 Fungicides: Bumper/Bim: 46 €/ha & \\
\hline \multirow{2}{*}{ Farmer B } & \multirow{2}{*}{8.721} & \multirow{2}{*}{728} & Adob: 195-36-44:271€/ha & \\
\hline & & & 3 Herbicides: Ronstar/Viper/BasagranM: 178 €/ha & \\
\hline
\end{tabular}




\begin{tabular}{|c|l|c|}
\hline & $\begin{array}{l}\text { 3 Fungicides: Folicur/Propiconazol+Bim/Procloraz: } \\
64 \text { €/ha }\end{array}$ & $\begin{array}{c}\text { Less Profit } \\
\text { Higher } \\
\text { Pesticides }\end{array}$ \\
\hline \multicolumn{2}{|c|}{ SAME YIELD, HIGHER PROFIT, REDUCED COST, MINIMIZE PESTICIDES \& } \\
FERTILIZERS
\end{tabular}

Table 6. Showcase for optimization of resource allocation

One of the main practices applied during a specific campaign emphasizes the reduction of herbicides and fungicides replacing potassium, sulfate, bionomic phosphate, and urea by ammonium sulfate. While maintaining profitable yield and reducing costs, this substitution plays a major role on environmental preservation by minimizing methane emission. According to Bufogle et al. (1998), ammonium sulfate, as source of nitrogen, has a lower level of methane emission compared to urea.

Another impact of applying waste and water management techniques is the preservation of the ecosystem and the protection of natural resources (Barth and Melin, 2018). The use of adequate and appropriate doses of fertilizers and pesticides ensures better environmental performances of farms by minimizing waste and reducing water pollution (Zhao et al., 2010). The program adopts the standards and guidelines of the Plant Health Service in relation to phytosanitary warnings, taking into account meteorological conditions and levels of inoculum (Normes OEPP, 2018). Farmers attempt to avoid water circulation in cultivated lands when using herbicides in order to reduce the likelihood of water contamination.

\begin{tabular}{|l|r|r|r|r|r|r|}
\hline ENVIRONMENTAL IMPACT & $\begin{array}{r}\text { Sub- } \\
\text { EVALUATION }\end{array}$ & Coordinator & $\begin{array}{r}\text { Co- } \\
\text { partner }\end{array}$ & Intermediary & $\begin{array}{r}\text { Technical } \\
\text { support }\end{array}$ & $\begin{array}{r}\text { End- } \\
\text { users }\end{array}$ \\
\hline Reduced consumption of water and energy & 6.71 & 7.00 & 10.00 & 7.36 & 8.68 & 6.28 \\
\hline Waste and resources management & 7.67 & 7.00 & 10.00 & 6.36 & 8.90 & 7.71 \\
\hline Reduced contamination and disease & 7.96 & 7.00 & 10.00 & 7.04 & 8.28 & 8.05 \\
\hline Preservation of a breed/species & 4.54 & 5.10 & 5.00 & 3.90 & 3.62 & 4.73 \\
\hline $\begin{array}{l}\text { Controlled pesticides/fertilizers/fungicides } \\
\text { dosage }\end{array}$ & 8.37 & 8.10 & 10.00 & 8.56 & 9.08 & 8.23 \\
\hline Decrease in GHG emissions/CO2 emission & 7.96 & 8.00 & 10.00 & 7.27 & 8.36 & 7.98 \\
\hline Protection of water quality & 7.74 & 8.10 & 10.00 & 6.69 & 8.02 & 7.83 \\
\hline Number of hectares certified & 6.95 & 6.40 & 5.00 & 5.39 & 5.94 & 7.39 \\
\hline Conservation of biodiversity & 7.83 & 8.00 & 10.00 & 6.77 & 8.28 & 7.89 \\
\hline Sustain organic farming & 4.66 & 5.00 & 2.00 & 3.99 & 4.26 & 4.88 \\
\hline Total average of environmental impact & $\mathbf{7 . 0 3}$ & $\mathbf{6 . 9 7}$ & $\mathbf{8 . 2 0}$ & $\mathbf{6 . 3 3}$ & $\mathbf{7 . 3 4}$ & $\mathbf{7 . 1 0}$ \\
\hline
\end{tabular}




\begin{tabular}{|l|r|r|r|r|r|r|}
\hline $\begin{array}{l}\text { Importance weight of environmental } \\
\text { impact (\%) }\end{array}$ & 19.56 & 20.00 & 25.00 & 25.63 & 22.00 & 18.08 \\
\hline Sample size (N) & 28 & 1 & 1 & 8 & 5 & 13 \\
\hline
\end{tabular}

Table 7. Stakeholders' evaluation of the environmental impact

\subsubsection{Health impact}

The improvement of crops' quality and the nutritional status of soil have a direct impact on the health and well-being of consumers, farmers, and end-users (Rayee et al., 2018; Sabiha and Rahman, 2018); sustainable farming practices would meet consumer needs for food security, food safety, and product quality (Table 8). Moreover, reducing the exposure of rice growers to chemical hazards is identified as another health impact (Rahman, 2003). The application of reduced doses of fertilizers and pesticides minimizes the risk and sanitary damages that might affect farmers and the environment (Sabiha et al., 2016). Chemicals' calibration sessions assure appropriate methods for effective dosage application, which in return reduce the drifting of hazardous products to other fields.

\begin{tabular}{|l|r|r|r|r|r|r|}
\hline HEALTH IMPACT EVALUATION & $\begin{array}{c}\text { Sub- } \\
\text { indicators }\end{array}$ & Coordinator & $\begin{array}{c}\text { Co- } \\
\text { partner }\end{array}$ & Intermediary & $\begin{array}{c}\text { Technical } \\
\text { support }\end{array}$ & $\begin{array}{c}\text { End- } \\
\text { users }\end{array}$ \\
\hline $\begin{array}{l}\text { Promote good nutritional status and well-being of } \\
\text { the population }\end{array}$ & 7.08 & 5.50 & 2.00 & 7.23 & 8.04 & 7.10 \\
\hline $\begin{array}{l}\text { Reduce contamination level fulfilling the EU } \\
\text { regulation }\end{array}$ & 7.66 & 6.10 & 10.00 & 7.28 & 8.40 & 7.61 \\
\hline $\begin{array}{l}\text { Provide rich source of food with healthy chemical } \\
\text { composition to promote healthier eating habits: } \\
\text { protein, fibers, vitamins, minerals, and healthy oil }\end{array}$ & 7.51 & 5.00 & 7.00 & 6.32 & 4.70 & 8.09 \\
\hline Lower risk of having health problem: obesity etc. & 6.71 & 5.00 & 5.00 & 4.55 & 4.10 & 7.42 \\
\hline Improvement of the quality of the product & 8.32 & 7.50 & 8.00 & 8.02 & 8.44 & 8.38 \\
\hline $\begin{array}{l}\text { Minimize farm workers' exposure to chemical } \\
\text { hazards }\end{array}$ & 8.64 & 5.60 & 9.00 & 7.37 & 8.56 & 8.90 \\
\hline $\begin{array}{l}\text { Control of pathogens and microbial levels: assuring } \\
\text { food safety and high quality products }\end{array}$ & 7.85 & 5.50 & 9.00 & 6.85 & 5.14 & 8.36 \\
\hline
\end{tabular}




\begin{tabular}{|l|r|r|r|r|r|r|}
\hline $\begin{array}{l}\text { Promote animal welfare: feeding, growing } \\
\text { condition etc. }\end{array}$ & 6.33 & 0.10 & 1.00 & 3.17 & 2.76 & 7.50 \\
\hline Total average of health impact & $\mathbf{7 . 5 1}$ & $\mathbf{5 . 0 4}$ & $\mathbf{6 . 3 8}$ & $\mathbf{6 . 3 5}$ & $\mathbf{6 . 2 7}$ & $\mathbf{7 . 9 2}$ \\
\hline Importance weight of health impact (\%) & $\mathbf{1 1 . 1 4}$ & $\mathbf{5 . 0 0}$ & $\mathbf{1 5 . 0 0}$ & $\mathbf{6 . 9 0}$ & $\mathbf{4 . 4 0}$ & $\mathbf{1 2 . 7 0}$ \\
\hline Sample size (N) & $\mathbf{2 8}$ & $\mathbf{1}$ & $\mathbf{1}$ & $\mathbf{8}$ & $\mathbf{5}$ & $\mathbf{1 3}$ \\
\hline
\end{tabular}

Table 8. Stakeholders' evaluation of the health impact

\subsubsection{Capacity building}

Capacity building consists of various stages, such as interactive communication with the rice farmers, identification of their demands, knowledge initiation and training delivery, scientific advice, and technical guidance. It is measured as developing educational training, theoretical and practical knowledge production, and scientific publication (Table 9). In contrast to other impacts, the coordinator is assigned the highest importance weight compared to other stakeholders. This finding is not surprising given that the coordinator's involvement in the program development is the highest and that, due to his/her expertise in regard to the training and formation material, he/she tends to value capacity building more than end-users (beneficiaries of the program). In addition, this RDi project provides new insights for sustainable cultivation techniques and could be perceived as an effective tool to motivate farmers to adopt the "best practices" in other cultivations.

\begin{tabular}{|l|r|r|r|r|r|r|}
\hline CAPACITY BUILDING EVALUATION & $\begin{array}{c}\text { Sub- } \\
\text { indicators }\end{array}$ & Coordinator & $\begin{array}{c}\text { Co- } \\
\text { partner }\end{array}$ & Intermediary & $\begin{array}{c}\text { Technical } \\
\text { support }\end{array}$ & $\begin{array}{c}\text { End- } \\
\text { users }\end{array}$ \\
\hline $\begin{array}{l}\text { New scientific collaborations or partnerships } \\
\text { between the projects participants }\end{array}$ & 7.29 & 8.10 & 10.00 & 7.88 & 8.18 & 7.03 \\
\hline $\begin{array}{l}\text { Exchange of personal within project } \\
\text { partners/career advancement/formal } \\
\text { qualification }\end{array}$ & 7.63 & 8.80 & 10.00 & 8.62 & 7.82 & 7.38 \\
\hline $\begin{array}{l}\text { Adoption of the innovation in other } \\
\text { industry/sector }\end{array}$ & 6.23 & 7.40 & 10.00 & 5.73 & 5.42 & 6.28 \\
\hline $\begin{array}{l}\text { Provide insights and future research direction } \\
\text { in the agri-food field }\end{array}$ & 7.39 & 9.00 & 10.00 & 7.38 & 7.42 & 7.29 \\
\hline $\begin{array}{l}\text { Training and course formation: scientific } \\
\text { guidance and advice }\end{array}$ & 8.26 & 8.00 & 10.00 & 7.95 & 9.78 & 8.08 \\
\hline $\begin{array}{l}\text { Theoretical and practical knowledge } \\
\text { production }\end{array}$ & 8.40 & 9.40 & 10.00 & 8.07 & 9.82 & 8.22 \\
\hline
\end{tabular}




\begin{tabular}{|l|r|r|r|r|r|r|}
\hline $\begin{array}{l}\text { Continuous improvement and development of } \\
\text { new ideas }\end{array}$ & 8.12 & 8.30 & 9.00 & 7.83 & 9.04 & 8.03 \\
\hline $\begin{array}{l}\text { Innovative investigation techniques and } \\
\text { methods: as model for replication in different } \\
\text { domains }\end{array}$ & 7.17 & 7.00 & 8.00 & 7.72 & 7.16 & 7.08 \\
\hline Engagement of various actors involved & 7.09 & 9.70 & 10 & 8.55 & 9.08 & 6.51 \\
\hline Post-implementation evaluation and follow-up & 6.73 & 8.90 & 10 & 7.98 & 8.66 & 6.19 \\
\hline Total average of capacity building & $\mathbf{7 . 4 3}$ & $\mathbf{8 . 4 6}$ & $\mathbf{9 . 7 0}$ & $\mathbf{7 . 7 7}$ & $\mathbf{8 . 2 4}$ & $\mathbf{7 . 2 1}$ \\
\hline Importance weight of capacity building (\%) & $\mathbf{2 8 . 7 3}$ & $\mathbf{4 0 . 0 0}$ & $\mathbf{2 0 . 0 0}$ & $\mathbf{3 1 . 8 8}$ & $\mathbf{3 6 . 0 0}$ & $\mathbf{2 7 . 3 1}$ \\
\hline Sample size (N) & $\mathbf{2 8}$ & $\mathbf{1}$ & $\mathbf{1}$ & $\mathbf{8}$ & $\mathbf{5}$ & $\mathbf{1 3}$ \\
\hline
\end{tabular}

Table 9. Stakeholders' evaluation of the capacity building

Figure 6 displays the radar chart of the societal impact of the RDi program. It represents a summary of the multidimensional outcomes generated, revealing the importance score of the stakeholder-network for each impact category. As indicated, the stakeholder-network considers that this RDi reveals the highest importance scores for capacity building, environmental impact, and health impact.

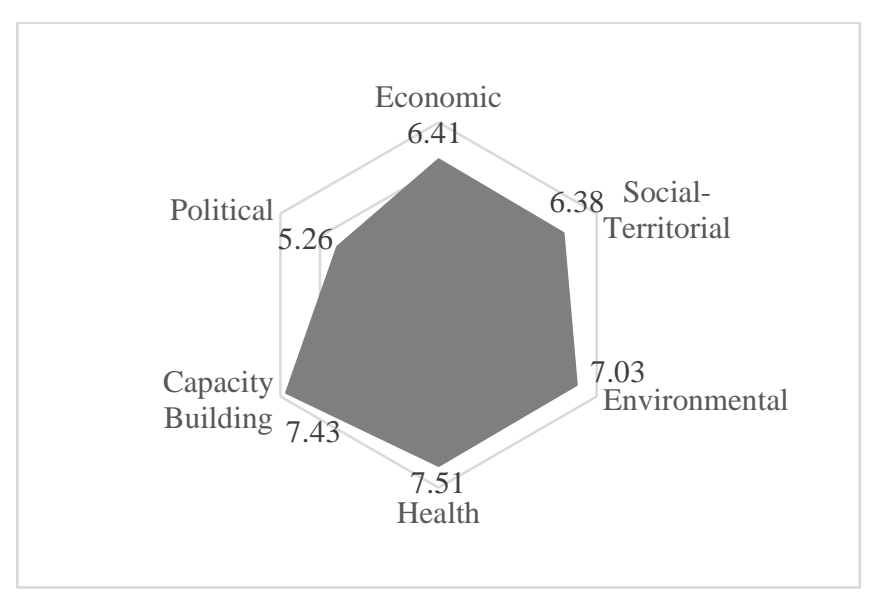

Figure 6. Radar chart of the societal impact

\section{Conclusion}

Currently, RIA is a key tool to improve the effectiveness of science and research for learning purposes and the management of impact within public research organizations (PROs). Belcher et al. (2017: 2) clearly state that "researchers are working deliberately not only to produce knowledge, but also to promote and facilitate the use of that knowledge to enable change, solve problems, and support innovation.” In this context, the objective of research has been extended to also become valuable and applicable to the society as a whole. Consistently, to address emergent concerns in regard to the benefits and investments in RDi, 
the RIA allows to evaluate four components of the Morgan and Grant model (2013): (1) advocacy - to demonstrate the value of research to government, stakeholders, and the public; (2) allocation - to fund and prioritize research based on its potential value in various realms of society; (3) accountability - to monitor and measure the contribution of research to society; (4) analysis - to understand the contributions of science to changes in practice and policymaking.

The case study shows that research and innovation development in the agri-food sector have a dual benefit: not only do they generate scientific impact by targeting the academic community and scholars in the agriculture literature; they also generate societal impact by influencing the civil community and the ecosystem. Furthermore, results show multiple societal outcomes, indicating that the RDi project affects more than one impact dimension. However, the degree of importance is unevenly distributed along the six selected dimensions. In fact, the impact pathway supports the relevance of long-term investments in research and socio-economic partnerships for knowledge production to achieve broader impact on science. The collaboration and interaction between public and private organizations facilitate the interchange of skills and capitals and enhance the availability and accessibility of a wider spectrum of resources dedicated to research development. Thus, this cooperation between the two sectors might be perceived as a helpful tool to overcome obstacles faced along the impact pathway. To scale up the results, the major beneficiaries of this RDi are classified into four levels: individual, institutional, industrial, and territorial. The individual level consists of rice farmers and producers; the institutional level represents professional associations, agriculture organizations, cooperative firms, and technical centers; the industrial level reflects the rice industry, particularly in Catalonia and generally in Spain; finally, the territorial level represents the expansion of the impact to various areas such as the Ebro Delta, Valencia, and Seville. The RIA process could become an evaluative practice within PROs to inform research policies and management about the societal impact of RDi outputs. In addition, impact analysis involves institutional learning capacity and external communication purposes, allowing different users to better understand the impact of their own research and to foster exchanges with researchers and partners around these issues.

The case study analysis indicates that the introduction of sustainability performance and green strategies shows promising lines to improve the growth and productivity of the rice 
market. At the EU level, this research development can be considered a substantial initiative toward the application of EU regulations related to agri-food policies. The "global” impact can be an implicit inference of the adoption of Sustainable Development Goals (SDGs) Agenda 2030. The identified impact can be perceived as an indirect implication of the following SDGs: reduce poverty (SDG1); zero hunger (SDG2); clean water and sanitation (SDG6); industry, innovation and infrastructure (SDG9); reduce inequality (SDG10); responsible consumption and production (SDG12); and life on land (SDG15).

Some shortcomings of our analysis as well as proposals for future research may be pointed out. One limitation of this study is the sample size of stakeholders; collecting additional data would increase the reliability and robustness of the results. In addition, a complementary approach based on ex-post and ex-ante evaluation merits further attention to improve RIA's ability to use a rich dataset, as well as qualitative and quantitative measures, to understand and report on the mechanisms that generate impact.

\section{Acknowledgement}

This study was supported by the Institute of Agri-food Research and Technology (IRTA) and the Universitat Politècnica de Catalunya through the project entitled “Assessment of the Societal Impact of Research and Innovation in the Agro-food sector”. The financing received from these organizations is gratefully acknowledged.

\section{References}

Acosta, P., Curt, M. D., 2019. Understanding the expansion of oil palm cultivation: A casestudy in Papua. J. Clean. Prod. 219, 199-216. https://doi.org/10.1016/j.jclepro.2019.02.029 Alston, J. M., Pardey, P. G., James, J. S., Andersen, M. A., 2009. The economics of agricultural R\&D. Annu. Rev. Resour. Econ. 1, 537-565. https://doi.org/10.1146/annurev.resource.050708.144137

Altieri, M. A., Nicholls, C. I., 2004. Biodiversity and pest management in agroecosystems. Food Product Press, New York.

Argote, L., Ingram, P., 2000. Knowledge transfer: a basis for competitive advantage in firms. Organ. Behav. Hum. Decis. Process. 82, 150-169. https://doi.org/10.1006/obhd.2000.2893

Andersen, M.A., Song, W., 2013. The Economic impact of public agricultural research and development in the United States. Agric. Econ. 44, 287-295.

Bacharach, S. B., Lawler, E. J., 1980. Power and politics in organizations. San Francisco: Jossey- Bass. 
Barth, H., Melin, M., 2018. A Green lean approach to global competition and climate change in the agricultural sector - A Swedish case study. J. Clean. Prod. 204, 183-192. https://doi.org/10.1016/j.jclepro.2018.09.021

Belcher, B., Suryadarma, D., Halimanjaya, A., 2017. Evaluating policy-relevant research: lessons from a series of theory-based outcomes assessments. Palgrave Commun. 3, 17017. https://doi.org/10.1057/palcomms.2017.17

Bervejillo, J.E., Alston, J.M. and Tumber, K.P., 2012. The benefits from public agricultural research in Uruguay. Australian J. Agric. Resour. Econ. 56, 475-497.

Bilali, H. E., 2019. Research on agro-food sustainability transitions: A systematic review of research themes and an analysis of research gaps. J. Clean. Prod. 221, 353-364. https://doi.org/10.1016/j.jclepro.2019.02.232

Birkhaeuser, D., Evenson, R. E., Feder, G., 1991. The economic impact of agricultural extension: A review. Econ. Dev. Cult. Ch. 39, 607-650. https://doi.org/10.1086/451893

Bornmann, L., 2013. What is societal impact of research and how can it be assessed? A literature survey. J. Am. Soc. Inf. Sci. Technol. 64, 217-233. https://doi.org/10.1002/asi.22803

Brandon, P., 1998. Stakeholder participation for the purpose of helping ensure evaluation validity: Bridging the gap between collaborative and non-collaborative evaluations. The Am. J. Eval. 19, 325-337. https://doi.org/10.1016/s1098-2140(99)80215-X

Bufogle, A., Bollich, P. K., Kovar, J. L., Lindau, C. W., Macchiavellid, R. E., 1998. Comparison of ammonium sulfate and urea as nitrogen sources in rice production. J. Plant. Nutr. 21, 1601-1614. https://doi.org/10.1080/01904169809365507

Cai, Y., Golub, A. A., Hertel, T. W., 2017. Agricultural research spending must increase in $\begin{array}{lllll}\text { light of future uncertainties. Food Policy. } & 70,\end{array}$ https://doi.org/10.1016/j.foodpol.2017.06.002

CIHEAM, 1997. Rice production and research in Spain. In: Chataigner J. (ed.). Activités de recherche sur le riz en climat méditerranéen. Montpellier (Cahiers Options Méditerranéennes) 24, 161-164.

Cousins, J. B., Whitmore, E., 1997. Framing participatory evaluation. Paper presented at the annual meeting of the Canadian Evaluation Society, Ottawa.

Cvitanovic, C., Mcdonald, J., Hobday, A., 2016. From science to action: Principles for undertaking environmental research that enables knowledge exchange and evidence-based decision-making. J. Envir. Manag. 183, 864-874. https://doi.org/ 10.1016/j.jenvman.2016.09.038

Das, K., (2007). Protection of Geographical Indications: An Overview of Select Issues with Particular Reference to India. SSRN Electronic Journal. https://doi.org/10.2139/ssrn.1587372

De Jong, S., Barker, K., Cox, D., Sveinsdottir, T., Van den Besselaar, P., 2014. Understanding societal impact through productive interactions: ICT Research as a Case. Res. Eval. 23, 89-102. https://doi.org/10.1093/reseval/rvu001

Dendena, B., Corsi, S., 2015. The environmental and social impact assessment: A further step towards an integrated assessment process. J. Clean. Prod. 108, 965-977.

Donovan, C., 2011. State of the art of assessing research impact: Introduction to a special issue. Res. Eval. 20, 175-9. https://doi.org/10.3152/095820211X13118583635918

Donovan, C., Hanney, S., 2011. The 'Payback Framework' explained. Res. Eval. 20, 181183. https://doi.org/10.3152/095820211X13118583635756

Ebro foods, 2018. Promoting biodiversity benefits sustainable rice production. 
www.ebrofoods.es/en/news/promoting-biodiversity-benefits-sustainable-rice-production18-04/.

FAS-USDA, 2012. Spain Rice Market in the Iberian Peninsula Spanish Rice ... (2012). Retrieved from https://gain.fas.usda.gov/Recent GAIN Publications/Rice Market in the Iberian Peninsula - Spanish Rice Producers to swi_Madrid_Spain_8-20-2012.pdf

Ferrero, A., Tinarelli, A., 2008. Rice cultivation in the E.U. ecological conditions and agronomical practices. Pestic. Risk Asses. in Rice Paddies. 1-24. https://doi.org/10.1016/B978-044453087-5.50002-3

Freeman, C. (1984). The Economics of industrial innovation. Pinter, London.

Fuglie, K.O., Heisey, P.W., 2007. Economic returns to public Agricultural research. Economic Brief 10, USDA/ERS.

Garnett, T., Appleby, M.C., Balmford, A., Bateman, I.J., Benton, T.G., Bloomer, P., Burlingame, B., Dawkins, M., Dolan, L., Fraser, D., Herrero, M., Hoffmann, I., Smith, P., Thornton, P.K., Toulmin, C., Vermeulen, S.J., Godfray, H.C.J., 2013. Sustainable intensification in agriculture: premises and policies. Sci. 341, 33-34. https://doi.org/10.1126/science.1234485

Gaunand, A., Hocdé, A., Lemarié, S., Matt, M., Turckheim, E., 2015. How does public agricultural research impact society? A characterization of various patterns. Res. Policy. 44, 849-861. https://doi.org/10.1016/j.respol.2015.01.009

Gaunand, A., Colinet, L., Joly, P.B., Matt, M., 2017. Counting what really counts? Assessing the political impact of science. J. Technol. Transf. 1-23. https://doi.org/10.1007/s10961-0179605-9

Guinea, J., Sela, E., Gómez-Núñez, A. J., Mangwende, T., Ambali, A., Ngum, N., . . . Thepthien, B., 2015. Impact oriented monitoring: A new methodology for monitoring and evaluation of international public health research projects. Res. Eval. 24, 131-145. https://doi.org/10.1093/reseval/rvu034

Gurr, G. M., Wratten, S. D., Altieri, M.A., 2004. Ecological engineering for pest management. Advances in habitat manipulation for arthropods. CSIRO, Australia.

Hamdoun, M., Jabbour, C. J., Othman, H. B., 2018. Knowledge transfer and organizational innovation: Impacts of quality and environmental management. J. Clean. Prod. 193, 759-770. https://doi.org/10.1016/j.jclepro.2018.05.031

Holland, J. M., 2004. The environmental consequences of adopting conservation tillage in Europe: reviewing the evidence. Agric. Ecosyst. Environ. 103, 1-25. https://doi.org/10.1016/j.agee.2003.12.018

Horton, D., Mackay, R., 2003. Using evaluation to enhance institutional learning and change: Recent experiences with agricultural research and development. Agric. Syst. 78, 127-142. https://doi.org/10.1016/S0308-521X(03)00123-9

Huang, S., Odum, H. T., 1991. Ecology and economy: Energy synthesis and public policy in Taiwan. J. Envir. Manag. 32, 313-333. https://doi.org/10.1016/s0301-4797(05)80069-6

Hussain, S., Peng, S., Fahad, S., Khaliq, A., Huang, J., Cui, K., Nie, L., 2014. Rice management interventions to mitigate greenhouse gas emissions: A review. Envir. Sci. Pollut. Res. 22, 3342-3360. https://doi.org/10.1007/s11356-014-3760-4

Idescat, Statistical institute of Catalonia (2017). Agricultural production. By products. Provinces. (n.d.). Retrieved from https://www.idescat.cat/pub/?id=aec\&n=446\&lang=en

Jena, P. R., Grote, U., 2012. Impact evaluation of traditional basmati rice cultivation in Uttarakhand State of Northern India: What implications does it hold for Geographical Indications? World. Dev. 40(9), 1895-1907. https://doi.org/10.1016/j.worlddev.2012.04.004 
Joly, P., Gaunand, A., Colinet, L., Larédo, P., Lemarié, S., Matt, M., 2015. ASIRPA: A comprehensive theory-based approach to assessing the societal impacts of a research organization. Res. Eval. 24, 440-453. https://doi.org/10.1093/reseval/rvv015

Josling, T., Roberts, D., Orden, D., 2004. Food regulation and trade: Toward a safe and open global system. Peterson Institute Press: All Books. Peterson Institute for International Economics, 347.

Liao, J., Hu, Y., Zhang, H., Liu, L., Liu, Z., Tan, Z., Wang, G., 2018. A rice mapping method based on time-series Landsat data for the extraction of growth period characteristics. Sustain. 10, 2570. https://doi.org/10.3390/su10072570

Loorbach, D., Frantzeskaki, N., Avelino, F., 2017. Sustainability transitions research: transforming science and practice for societal change. Annu. Rev. Envir. Resour. 42, 599626. https://doi.org/10.1146/annurev-environ-102014-021340

Lu, H., Bai, Y., Ren, H., Campbell, D. E., 2010. Integrated emergy, energy and economic evaluation of rice and vegetable production systems in alluvial paddy fields: Implications for agricultural policy in China. J. Envir. Manag. 91, 2727-2735. https://doi.org/10.1016/j.jenvman.2010.07.025

Lwoga, E. T., Stilwell, C., Ngulube, P., 2011. Access and use of agricultural information and knowledge in Tanzania. Libr. Rev. 5, 383-395. https://doi.org/10.1108/00242531111135263 Markard, J., Raven, R., Truffer, B., 2012. Sustainability transitions: an emerging field of research and its prospects. Res. Policy. 41, 955-967. https://doi.org/10.1016/j.respol.2012.02.013

Matt, M., Gaunand, A., Joly, P., Colinet, L., 2017. Opening the black box of impact - Idealtype impact pathways in a public agricultural research organization. Res. Policy. 46, 207218. https://doi.org/10.1016/j.respol.2016.09.016

Miller, S. A., Cunningham, P. R., Harvey, J. T., 2019. Rice-based ash in concrete: A review of past work and potential environmental sustainability. Resour. Conserv. Recycl. 146, 416430. https://doi.org/10.1016/j.resconrec.2019.03.041

Morgan, J. M., Grant, J., 2013. Making the grade: Methodologies for assessing and evidencing research impact. In: Dean, A., Wykes, M., and Stevens, H. (eds). 7 Essays on Impact. University of Exeter.

Normes OEPP, 2018. European and Mediterranean Plant Protection Organization: Standards Phytosanitary treatments. EPPO Bulletin. 48, 533-535.

Noya, I., González-García, S., Bacenetti, J., Fiala, M., Moreira, M. T., 2018. Environmental impacts of the cultivation-phase associated with agricultural crops for feed production. J. Clean. Prod. 172, 3721-3733. https://doi.org/10.1016/j.jclepro.2017.07.132

OECD, 2011. Towards green growth - a summary for policy makers. Paris. https://doi.org/10.1787/9789264111318-en

Prändl-Zika, V., 2008. From subsistence farming towards a multifunctional agriculture: Sustainability in the Chinese rural reality. J. Envir. Manag. 87, 236-248. https://doi.org/10.1016/j.jenvman.2006.10.028

Penfield, T., Baker, M. J., Scoble, R., Wykes, M. C., 2013. Assessment, evaluations, and definitions of research impact: A review. Res. Eval. 23, 21-32. https://doi.org/10.1093/reseval/rvt021

Rahman, S., 2003. Environmental impacts of modern agricultural technology diffusion in Bangladesh: An analysis of farmers' perceptions and their determinants. J. Envir. Manag. 68, 183-191. https://doi.org/10.1016/S0301-4797(03)00066-5 
Rangnekar, D., 2004. The Socio-Economics of Geographical Indications. https://doi.org/10.7215/ip_ip_20040501b

Rayee, R., Tran, H., Xuan, T., Khanh, T., 2018. Imposed water deficit after anthesis for the improvement of macronutrients, quality, phytochemicals, and antioxidants in rice grain. Sustain. 10, 4843. https://doi.org/10.3390/su10124843

Reig, E., Picazo-Tadeo, A., Estruch, V., 2008. The policy analysis matrix with profit-efficient data: Evaluating profitability in rice cultivation. Span. J. Agric. Res. 6, 309-319. https://doi.org/10.5424/sjar/2008063-324

Sabiha, N., Rahman, S., 2018. Environment-Smart agriculture and mapping of interactions among environmental factors at the farm level: A directed graph approach. Sustain. 10, 1580. https://doi.org/10.3390/su10051580

Sabiha, N., Salim, R., Rahman, S., Rubzen, M.F., 2016. Measuring environmental sustainability in agriculture: A composite environmental impact index approach. J. Envir. Manag. 166, 84-93. https://doi.org/10.1016/j.jenvman.2015.10.003

Salter, A. J., Martin, B. R., 2001. The economic benefits of publicly funded basic research: a critical review. Res. Policy. 30, 509-532. https://doi.org/10.1016/s0048-7333(00)00091-3

Sanchez-Escobar, F., Coq-Huelva, D., Sanz-Cañada, J., 2018. Measurement of sustainable intensification by the integrated analysis of energy and economic flows: Case study of the olive-oil agricultural system of Estepa, Spain. J. Clean. Prod. 201, 463-470. https://doi.org/10.1016/j.jclepro.2018.07.294

Spaapen, J. M., Van Drooge, L., 2011. Introducing productive interactions in social assessment. Res. Eval. 20, 211-218. https://doi.org/10.3152/095820211X12941371876742

Stobart, R., Morris, N. L., Fielding, H., Leake, A., Egan, J., Burkinshaw, R., 2015. Developing the use of cover crops on farm through the Kellogg's Origins grower programme. Aspects Appl. Biol. 129, 27-33.

The Lisbon Strategy 2000 - 2010 An analysis and evaluation of the methods used and results achieved - $\quad$ Think Tank. (n.d.). Retrieved from http://www.europarl.europa.eu/thinktank/en/document.html?reference=IPOLEMPL_ET(2010)440285

The United Nations 2030 Agenda for Sustainable Development (2015, October 04). Retrieved from https://www.un.org/sustainabledevelopment/sustainable-development-goals/ The Kellogg's Origins ${ }^{\mathrm{TM}}$ Program helps farmers worldwide. (2019). Retrieved from http://www.openforbreakfast.com/en_US/content/sustainability/working-withfarmers.html.

Van Nguyen, N. Ferrero, A., 2006. Meeting the challenges of global rice production. Paddy Water Envir. 4, 1-9. https://doi.org/10.1007/s10333-005-0031-5

Weißhuhn, P., Helming, K., Ferretti, J., 2017. Research impact assessment in agricultureA review of approaches and impact areas. Res. Eval. 27, 36-42. https://doi.org/10.1093/reseval/rvx034

Winsberg, M. D., 1980. Concentration and specialization in United States agriculture, 19391978. Econ. Geogr. 56, 183-189. https://doi.org/10.2307/142711

Witzke, H., Noleppa, S., 2016. The High Value to Society of Modern Agriculture: Global Food Security, Climate Protection, and Preservation of the Environment - Evidence from the European Union. Front. Econ. Glob. Food Secur. in a Food Abund. World. 16, 55-65. https://doi.org/10.1108/s1574-871520150000016016 
Zhao, L., Wu, L., Dong, C., Li, Y., 2010. Rice yield, nitrogen utilization and ammonia volatilization as influenced by modified rice cultivation at varying nitrogen rates. Agric. Sci. 1, 10-16. https://doi.org/10.4236/as.2010.11002 